\title{
Effects of nutrient impoverishment on phytoplankton biomass: a mesocosms experimental approach in a shallow eutrophic reservoir (Garças Pond), São Paulo, southeast Brazil
}

\author{
LUCIANE O. CROSSETTI ${ }^{1,3}$ and CARLOS E. DE M. BICUDO ${ }^{2}$
}

(received: April 15, 2004; accepted: November 5, 2004)

\begin{abstract}
Effects of nutrient impoverishment on phytoplankton biomass: a mesocosms experimental approach in a shallow eutrophic reservoir (Garças Pond), São Paulo, southeast Brazil). Nutrient impoverishment in mesocosms was carried out in a shallow eutrophic reservoir aiming to evaluate the nutrient removal technique as a method for eutrophication reduction. Garças Pond is located in the Parque Estadual das Fontes do Ipiranga Biological Reserve situated in the southeast region of the municipality of São Paulo. Three different treatments were designed, each consisting of two enclosures containing 360 liters of water each. Mesocosms were made of polyethylene bags and PVC pipes, and were attached to the lake bottom. Treatment dilutions followed Carlson's trophic state index modified by Toledo and collaborators, constituting the oligotrophic, mesotrophic, and eutrophic treatments. Ten abiotic and 9 biological samplings were carried out simultaneously. Trophic states previously calculated for the treatments were kept unaltered during the entire experiment period, except for the mesotrophic mesocosms in which TP reached oligotrophic concentrations on the $31^{\text {st }}$ day of the experiment. In all three treatments a reduction of DO was observed during the study period. At the same time, $\mathrm{NH}_{4}{ }^{+}$and free $\mathrm{CO}_{2}$ rose, indicating decomposition within the enclosures. Nutrient impoverishment caused $\mathrm{P}$ limitation in all three treatments during most of the experiment period. Reduction of algal density, chlorophyll $a$, and phaeophytin was observed in all treatments. Competition for nutrients led to changes in phytoplankton composition. Once isolated and diluted, the mesocosms' trophic state did not change. This led to the conclusion that isolation of the allochthonous sources of nutrients is the first step for the recovery of the Garças Pond.
\end{abstract}

Key words - biomass, impoverishment, mesocosms, phosphorus, phytoplankton

RESUMO - (Efeitos do empobrecimento de nutrientes sobre a biomassa fitoplanctônica: estudo experimental (mesocosmos) em reservatório eutrófico raso (Lago das Garças), São Paulo, Brasil sudeste). Empobrecimento de nutrientes foi realizado em mesocosmos localizados em reservatório eutrófico raso visando testar a técnica de remoção de nutrientes como método para diminuir o teor de eutrofização. O Lago das Garças situa-se na Reserva Biológica do Parque Estadual das Fontes do Ipiranga, região sudeste do Município de São Paulo. Foram delineados três tipos de tratamentos, cada qual composto por dois mesocosmos contendo 360 litros de água. Os mesocosmos foram construídos com sacos de polietileno transparente e canos de PVC e fixados próximos à região litoral do reservatório. As diluições dos tratamentos seguiram o Índice de Estado Trófico de Carlson modificado por Toledo e colaboradores, constituindo os tratamentos oligotrófico, mesotrófico e eutrófico. Foram realizadas, simultaneamente, 10 amostragens abióticas e nove bióticas. As trofias previamente estabelelecidas mantiveram-se imutáveis nos mesocosmos durante a maior parte do período experimental. Foi observada queda nas concentrações de OD em todos os tratamentos durante o período de estudo e aumento nos valores de amônio e gás carbônico livre indicando processo de decomposição nos tratamentos. O empobrecimento de nutrientes provocou limitação por P nos três tratamentos na maioria dos dias do experimento e proporcionou redução da biomassa fitoplanctônica, demonstrado pela diminuição da densidade total do fitoplâncton nos três tratamentos através da queda dos valores de clorofila $a$ e feofitina. A competição pelos nutrientes restantes nos mesocosmos após diluição provocou alteração na composição da comunidade fitoplanctônica nos três tratamentos. O isolamento das fontes alóctones de nutrientes é passo primordial na recuperação do Lago das Graças.

Palavras-chave - biomassa, empobrecimento, fitoplâncton, fósforo, mesocosmos

\section{Introduction}

Eutrophication is a skyrocketing problem worldwide. Increasing nutrient concentration in lakes

\footnotetext{
1. Doctoral student, Universidade de São Paulo, Ribeirão Preto, SP, Brazil.

2. Instituto de Botânica, Caixa Postal 4005, 01061-970 São Paulo, SP, Brazil. (cbicudo@terra.com.br)

3._Correponding author: lcrossetti@terra.com.br
}

and reservoirs around the world directly affects local biological communities and consequently leads to scientists and politicians both to be concerned with problems caused by eutrophication. Today algal blooms, caused by the excessive nutrient supply, are very common.

Nutrient reversion techniques have been continually studied and applied in an attempt to decrease artificial eutrophication's harmful effects. Mesocosms 
experiments are employed to understand nutrient dynamics and their effects on biological communities, as well as to test such techniques for impacted systems recovery.

Up to now, studies using mesocosms in Brazil only aimed at understanding the effects of nutrient (nitrogen and / or phosphorus) enrichment in oligo and mesotrophic systems (e.g. Suzuki 1991, Cerrao et al. 1991, Ferragut 1999). Nutrient impoverishment effects studies had never been carried out in Brazil, but abroad through different techniques aiming at "in situ" or "ex situ" in laboratory environment recovery (e.g. Pearl \& Bowles 1987, Dodds \& Randel 1992, Dodds et al. 1993). Other works not using mesocosms were carried out to describe the successional changes in the phytoplankton community after recovery and the nutrient concentration reduction during the restoration process of eutrophicated systems (e.g. Rip et al. 1992, Perrow et al. 1994, Padisák \& Reynolds 1998, Cronberg et al. 1999, Cronberg 1999, Annadotter et al. 1999, Barbieri \& Simona 2001).

Among projects devoted to the recovery of systems in tropical reservoirs are Altafin et al. (1995) which studied the Paranoá Lake, in the Federal District, and Bozzelli et al. (2000) which studied the Batata Lake, in the northern state of Pará, both systems still undergoing recovery, the first from domestic effluents and the latter from bauxite mining.

Mesocosms studies were presently designed to simulate oligotrophication through nutrient supply reduction by creating new trophic conditions and, consequently, leading to changes in the community structure. It is hoped that knowledge of the responses and the survival strategies of the phytoplankton community will help to evaluate the impoverishment technique as a method for decreasing eutrophication in shallow lakes and reservoirs.

Present investigation aimed at studying the effects of nutrient dilution on the phytoplankton biomass and composition as a recovery factor to understand the changes under the new trophic condition.

\section{Material and methods}

Study Area - The Garças Pond is located in the Parque Estadual das Fontes do Ipiranga Biological Reserve, situated in the southeast region of the municipality of São Paulo

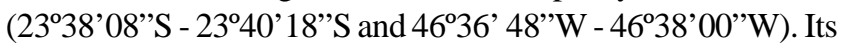
mean altitude is $798 \mathrm{~m}$ and the total area 526.4 ha (Fernandes et al. 2002). The park is one of the few Atlantic Forest remnants in the midst of a very densely urbanized region of the city of São Paulo (Barbosa et al. 2002).
The system, a reservoir recently classified as eutrophic (D. Bicudo et al. 2002), is the most affected system by human action in the park. It is a very shallow reservoir, with maximum depth $4.7 \mathrm{~m}$. Its total surface area is $88,156 \mathrm{~m}^{2}$, maximum length $512 \mathrm{~m}$, maximum width $319.5 \mathrm{~m}$, and the mean residence time is around 45 days (C. Bicudo et al. 2002). The reservoir has seven tributaries, four of which bring in natura sewage and only one is oligotrophic. There is only one outlet (Carmo et al. 2002).

Experimental procedures - Study was carried out from 10 August to 9 September 2000. Samplings were performed during the morning (ca. 08:00 AM) at 3-day intervals until the $20^{\text {th }}$ day and at 5-day intervals during the remaining period (for 31 days).

Three different treatments were designed, each consisting of 2 enclosures containing 360 liters of water each. Mesocosms were built of polyethylene bags and PVC pipes, and were fixed on the lake bottom distant $2 \mathrm{~m}$ one from another to prevent contamination among them (figure 1). Treatment dilutions were made using different proportions of the Garças Pond water and of one reservoir's oligotrophic tributary's water (table 1) following Carlson's trophic state index modified by Toledo et al. (1983) to constitute the oligotrophic $\left(\mathrm{O}_{1}\right.$ and $\left.\mathrm{O}_{2}\right)$, the mesotrophic $\left(M_{1}\right.$ and $\left.M_{2}\right)$, and the eutrophic $\left(E_{1}\right.$ e $\left.E_{2}\right)$ treatments (table 2). Ten abiotic and nine biological samplings were simultaneously carried out. Experimental impoverishment was obtained by dilution procedures and the defined trophic condition in each mesocosms remained unaltered throughout the experiment.

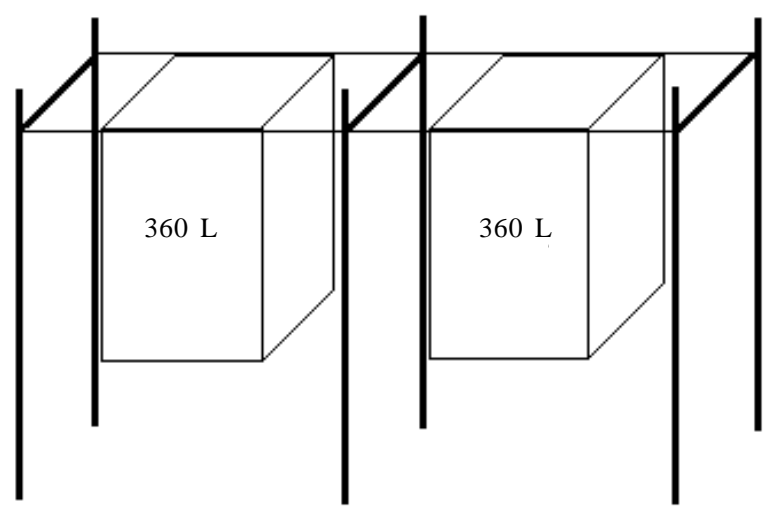

Figure 1. Scheme showing mesocosm's construction.

The following physical and chemical water variables were analyzed: temperature, electric conductivity, dissolved oxygen (DO) (Golterman et al. 1978), pH, alkalinity (Golterman \& Clymo 1971), free $\mathrm{CO}_{2}$, bicarbonate $\left(\mathrm{HCO}_{3}{ }^{-}\right)$and carbonate $\left(\mathrm{CO}_{3}{ }^{2-}\right)$ (Mackeret et al. 1978), total nitrogen (TN) (Valderrama 1981), ammonium $\left(\mathrm{NH}_{4}^{+}\right)$(Solorzano 1969), nitrate $\left(\mathrm{NO}_{3}^{-}\right)$and nitrite $\left(\mathrm{NO}_{2}^{-}\right)$(Mackeret et al. 1978), orthophosphate $\left(\mathrm{PO}_{4}^{3-}\right)$ and total dissolved phosphorus (TDP) (Strickland \& Parsons 1960), total phosphorus (TP) (Valderrama 1981), and $\mathrm{SiH}_{4} \mathrm{O}_{4}$ (Golterman et al. 1978). Mesocosms contents were always 
Table 1. Oligotrophic water volume and Garças reservoir (eutrophic) volume used for treatments’ dilutions.

\begin{tabular}{lccc}
\hline & $\begin{array}{c}\text { Oligotrophic } \\
\text { water }\end{array}$ & $\begin{array}{c}\text { Eutrophic } \\
\text { water }\end{array}$ & $\begin{array}{c}\text { Total water } \\
\text { volume }\end{array}$ \\
\hline Oligotrophic & $330 \mathrm{~L}$ & $30 \mathrm{~L}$ & $360 \mathrm{~L}$ \\
Mesotrophic & $300 \mathrm{~L}$ & $60 \mathrm{~L}$ & $360 \mathrm{~L}$ \\
Eutrophic & - & $360 \mathrm{~L}$ & $360 \mathrm{~L}$ \\
\hline
\end{tabular}

homogenized and the trophic state index in each treatment was tested before sampling. Mesocosms were installed in the littoral region to prevent human and shadow interference (figure 1).

Biological variables studied were algal density, chlorophyll $a$, and phaeophytin. For determination of chlorophyll $a$ and phaeophytin concentration, Whatman GF/F glass fiber filters ( $47 \mathrm{~mm}$ diameter, $0.6-0.7 \mu \mathrm{m}$ pore size) were used. Pigment extraction was done with ethanol 90\% as the organic solvent (Sartory \& Grobbelaar 1984). Spectrophotometric determination of chlorophyll $a$ and its degradation products followed Lorenzen's method described in Golterman et al. (1978) and Wetzel \& Likens (2000).

Table 2. Total phosphorus (TP) concentration following Carlson's trophic state index modified and total phosphorus concentrations in the mesocosms.

\begin{tabular}{|c|c|c|}
\hline & $\begin{array}{l}\text { Carlson’s trophic state } \\
\text { index modified by } \\
\text { Toledo et al. (1983) }\end{array}$ & $\begin{array}{l}\text { TP concentrations } \\
\text { in the treatments }\end{array}$ \\
\hline Oligotrophic & $<44 \mu g$ g.L $L^{-1}$ & $<20 \mu g$ g.L - $^{-1}$ \\
\hline Mesotrophic & 44-54 $\mu g P . L^{-1}$ & $45-50 \mu g P . L^{-1}$ \\
\hline Eutrophic & $>54 \mu g P . L^{-1}$ & $>58 \mu g P . L^{-1}$ \\
\hline
\end{tabular}

Taxonomic samples were preserved with $4 \%$ formaldehyde water solution (Bicudo 1990). Individual organisms were identified to species and, whenever possible, to infraspecific level.
Quantitative study was carried out according to Utermöhl (1958) and sedimentation procedures followed Lund et al. (1958). Organisms were quantified using the transect method and species rarefaction curve (Bicudo 1990).

Descriptive and exploratory univariate analysis was performed using the software MINITAB version 10.1 (State College). Multivariate descriptive analyses were processed employing Principal Component Analysis (PCA) to the abiotic data through covariance matrix with data transformation by ranging. For the Canonic Correspondence Analysis (CCA), the abiotic and biological data were also transformed by ranging. Softwares used were FITOPAC (Shepherd 1996) for data transformation and PC-ORD for Windows, version 3.0 (McCune \& Mefford 1997) for the analysis itself. Mean value comparisons among treatments were made by Variance Analysis (one way ANOVA). For mean comparisons and determination of the minimum significant difference among treatments Tukey test was used adopting the software SAS, version 6.12 (SAS Institute Inc. 1996).

\section{Results}

Environmental variables - Climatic factors equally influenced all three treatments, since the mesocosms were simultaneous and placed near each other in the Garças Pond (table 3).

Mesocosms water temperature mean value was $17.2^{\circ} \mathrm{C}$ with very little variation registered during the entire study period. Minimum and maximum values were $15.1^{\circ} \mathrm{C}$ and $19.3^{\circ} \mathrm{C}$, respectively.

In the eutrophic mesocosms, electric conductivity was always high, the highest values $\left(283.5 \mu \mathrm{S} . \mathrm{cm}^{-1}\right)$ being registered on the $15^{\text {th }}$ day. At the meso and oligotrophic treatments, the highest values were also observed on the $15^{\text {th }}$ day $\left(113.3 \mu \mathrm{S} . \mathrm{cm}^{-2}\right.$ and $66.5 \mu \mathrm{S} . \mathrm{cm}^{-2}$, respectively). Conductivity values detected at the meso and oligotrophic mesocosms showed that some oligotrophication process was in progress in the mesotrophic treatment, a fact confirmed by TP values (figure 2).

Table 3. Minimum and maximum values, between parenthesis, mean and standard deviation, and variation coefficients $(\mathrm{n}=31)$ of climatic variables during the study period.

\begin{tabular}{|c|c|c|c|c|}
\hline Feature & $\begin{array}{l}\text { Rain precipitation } \\
\text { (mm) }\end{array}$ & $\begin{array}{l}\text { Wind speed } \\
\left(\mathrm{m} \cdot \mathrm{s}^{-1}\right)\end{array}$ & $\begin{array}{c}\text { Air temperature } \\
\left({ }^{\circ} \mathrm{C}\right)\end{array}$ & $\begin{array}{c}\text { Solar radiation } \\
\left(\mu \mathrm{mol} . \mathrm{S}^{-1} \cdot \mathrm{m}^{-2}\right)\end{array}$ \\
\hline & $0.0-5.7$ & 2.5-9.1 & $5.1-32.4$ & $22.3-364.7$ \\
\hline Values & $(2.9 \pm 4.0)$ & $(5.8 \pm 4.6)$ & $(18.8 \pm 19.3)$ & $(193.5 \pm 197.7)$ \\
\hline VC(\%) & 137.9 & 79.6 & 103.0 & 102.2 \\
\hline
\end{tabular}


Dissolved oxygen decreased in all the systems during the experimental period. Free $\mathrm{CO}_{2}$ values in the eutrophic mesocosms remained low until the $12^{\text {th }}$ day, after which they rose to their maximum value (8.65 mg. $\mathrm{L}^{-1}$ ) on the $31^{\text {st }}$ day of the experiment. During the same day, the lowest registered $\mathrm{pH}$ value indicated photosynthetic activity decline. The same was observed in the other treatments. In the mesotrophic treatment, however, the highest free $\mathrm{CO}_{2}$ concentration (8.54 mg. $\mathrm{L}^{-1}$ ) was detected on the $12^{\text {th }}$ day, when the lowest $\mathrm{DO}$ and $\mathrm{pH}$ values were also observed (figure 2).

Eutrophic mesocosms' $\mathrm{pH}$ values decreased during the entire study period, reaching its lowest value (7.10) on the $31^{\text {st }}$ day. In the mesotrophic mesocosms, the
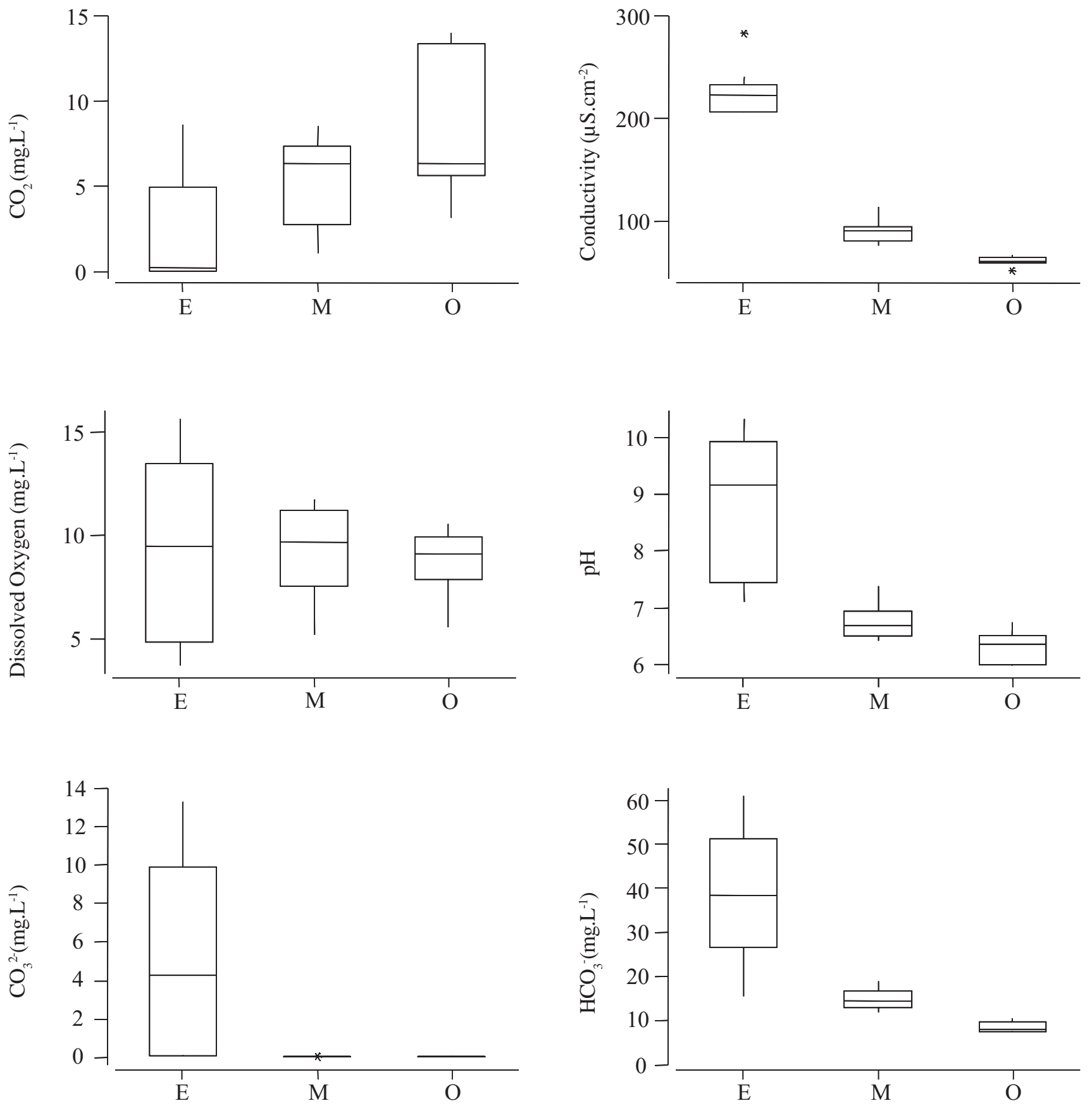

Figure 2. Boxplot (median, interquartile ranges, $\mathrm{n}=10$ ) of conductivity, bicarbonate $\left(\mathrm{HCO}_{3}^{-}\right)$, dissolved oxygen (DO), carbonate $\left(\mathrm{CO}_{3}\right)$, free $\mathrm{CO}_{2}$, and $\mathrm{pH}$ in three treatments during the experiment period. 
greatest value (7.37) was observed on the $6^{\text {th }}$ day and the lowest (6.42) on the $12^{\text {th }}$ day. In the oligotrophic mescosms, the greatest $\mathrm{pH}(6.74)$ value was on the $1^{\text {st }}$ day, whereas the lowest (5.98) was on the $3^{\text {rd }}$ day.

Nutrient impoverishment and the building structure of the mesocosms favored the increase of free $\mathrm{CO}_{2}$ concentration as well as the decrease of $\mathrm{pH}$ values, thus justifying the presently measured low alkalinity values (figure 2).

Nutrients - Orthophosphate $\left(\mathrm{PO}_{4}^{-3}\right)$ is the only soluble form of inorganic phosphorus that can be taken directly by algae (Wetzel 2001). Being quickly assimilated, its environmental concentration very often stays under the method's detection limit. Consequently, water samplings were enriched with $80 \mu \mathrm{g} . \mathrm{L}^{-1}$ of monobasic potassium phosphate and at the end of the chemical analysis sample concentrations were corrected by subtracting these from the values obtained to get the real orthophosphate concentrations. In the eutrophic treatment, the highest orthophosphate concentration $\left(9.08 \mu \mathrm{g} . \mathrm{L}^{-1}\right)$ occurred on the $6^{\text {th }}$ day, whereas at the meso and the oligotrophic treatments, the highest values were, respectively, $5.13 \mu \mathrm{g} . \mathrm{L}^{-1}$ and $3.14 \mu \mathrm{g} . \mathrm{L}^{-1}$, and occurred on the first day of study in both treatments. Values observed in all treatments remained low during the entire experiment period. Moura (1996) registered similar fact in study of phytoplankton succession at Garças pond and detected that the orthophosphate concentration at the system surface was below method's limit for detection. The low values presently observed in all mesocosms can be explained by the dilution procedure used and the phosphorus becoming the limiting nutrient (figure 3).

Total phosphorus (TP) was very important in this study, as concentrations were decisive for trophic state of mesocosms. Both highest (388.49 $\mu \mathrm{g} . \mathrm{L}^{-1}$ ) and lowest (160.89 $\left.\mu \mathrm{g} . \mathrm{L}^{-1}\right)$ TP values in the eutrophic treatment were registered on days 12 and 31, respectively. At the meso and oligotrophic treatments, the highest TP values (52.22 $\mu \mathrm{g} . \mathrm{L}^{-1}$ and $22.14 \mu \mathrm{g} . \mathrm{L}^{-1}$, respectively) occurred on $3^{\text {rd }}$ day. TP values in eutrophic and oligotrophic mesocosms were always within the established concentration range fixed by the Carlson trophic state index modified by Toledo et al. (1983). However, on the very last day of experiment, TP concentrations in the mesotrophic treatment $\left(25.03 \mu \mathrm{g} . \mathrm{L}^{-1}\right)$ reached values compatible with those established for oligotrophic systems, showing a clear tendency towards oligotrophication (figure 3).

Water pouring into the polyethylene bags during construction of mesocosms caused some oxygenation of treatments. This fact could have contributed to the high concentration of the oxygenated forms of nitrogen, such as nitrites $\left(\mathrm{NO}_{2}^{-}\right)$and nitrates $\left(\mathrm{NO}_{3}^{-}\right)$. All 3 treatments showed a decline in nitrite values during the beginning of the experiment ( $6^{\text {th }}$ day), the nitrite concentrations remaining low until the end of the study period (figure 3). Higher nitrate concentrations were also observed in all mesocosms due to oxygenation generated during mesocoms' installation. Nitrate values fell in the eutrophic treatments on days 3 and 6 , otherwise remaining low until the end of the study period. In the meso and oligotrophic treatments, oscillation of nitrate values was observed during most of the present study (figure 3).

Ammonium $\left(\mathrm{NH}_{4}^{+}\right)$concentrations in mesocosms grew during the entire study period. Rising ammonium values associated with $\mathrm{CO}_{2}$ rise and DO decline indicated presence of some decomposition process in all three treatments throughout experiment (figure 3). Mesocosms' water isolation from the lake effluent nutrient contribution, as well as its isolation from the sediment nutrient input may also have contributed to that.

Increase of total nitrogen (TN) values observed in all mesocosms during the first days of experiment was likely to have been stimulated by the highest nitrate and nitrite values registered during that time. In the eutrophic treatment, maximum TN values (6819.52 $\left.\mu \mathrm{g} . \mathrm{L}^{-1}\right)$ were registered on the $6^{\text {th }}$ day, whereas in the diluted treatments the greatest concentrations $\left(1367.27 \mu \mathrm{g} . \mathrm{L}^{-1}\right.$ and $965.61 \mu \mathrm{g} . \mathrm{L}^{-1}$, respectively, at the meso and oligotrophic treatments) occurred on day 3 (figure 3 ).

$\mathrm{N}$ : P molar ratio was calculated using the inorganic nutrients (nitrite, nitrate, ammonium, and orthophosphate) and total nutrients (total nitrogen and total phosphorus). Limitation by phosphorus ( $\mathrm{N}: \mathrm{P}$ rate $>16 \rightarrow \mathrm{P}$ limitation) was then detected in all treatments throughout most of the experiment period (table 4, figure 4).

Integrated analysis of environmental factors - Principal component analysis (PCA) indicated the following (table 5 , figure 5) main tendencies among the abiotic characteristics in the mesocosms: (1) Analysis explained $76.4 \%$ of data variability as shown on the first 2 ordination axes (table 5, figure 5); (2) Seven variables contributed more $(r>0.7)$ to ordination as shown on the $1^{\text {st }}$ axis: conductivity, $\mathrm{pH}$, total phosphorus, dissolved total phosphorus, total nitrogen, carbonate, and free $\mathrm{CO}_{2}$; (3) Other variables were also important $(\mathrm{r}>0.5)$ such as nitrates, bicarbonates, and orthophosphates; (4) For the $2^{\text {nd }}$ axis, dissolved oxygen and silicate were the most important variables $(r>0.7)$, followed by ammonium and bicarbonates $(r>0.5)$ (table 5 , figure 5). 

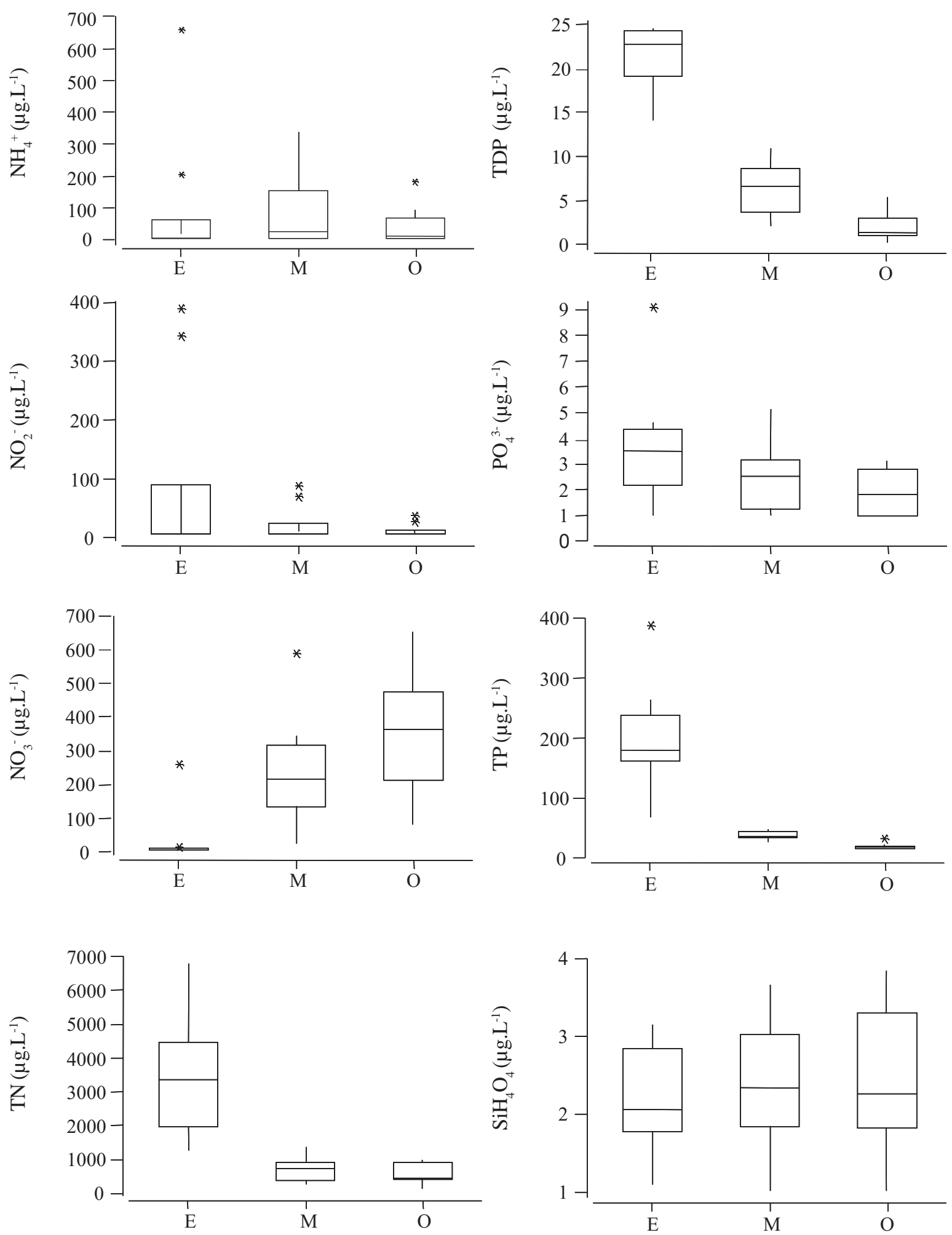

Figure 3. Boxplot (median, interquartile ranges, $\mathrm{n}=10$ ) of ammonium $\left(\mathrm{NH}_{4}^{+}\right)$, nitrite $\left(\mathrm{NO}_{2}^{-}\right)$, nitrate $\left(\mathrm{NO}_{3}^{-}\right)$, total nitrogen $(\mathrm{TN})$, total dissolved phosphorus (TDP), orthophosphate $\left(\mathrm{PO}_{4}{ }^{3-}\right)$, total phosphorus (TP), and silicate in three treatments during the experiment period. 
Table 4. Mean values of N:P (dissolved nutrients) and TN : TP ratio $(n=10)$ in three treatments during the experiment period.

\begin{tabular}{lcc}
\hline Treatments & TN : TP & $\mathrm{N}: \mathrm{P}$ \\
\hline Eutrophic & 34.5 & 105.7 \\
Mesotrophic & 41.1 & 171.1 \\
Oligotrophic & 71.0 & 202.8 \\
\hline
\end{tabular}

First axis (56.6 \%) clearly separated eutrophic treatments from oligotrophic ones, with the mesotrophic treatments occupying an intermediate position between the first two. So, PCA $1^{\text {st }}$ axis represented the trophic gradient, whereas the $2^{\text {nd }}$ axis $(19.8 \%)$ separated the treatments according to the temporal variation. At the positive side of axis 2, units of the experiment's first period were associated to DO values, confirming the highest DO values measured in the beginning of this study in all mesocosms. At the negative side of the $2^{\text {nd }}$ axis were located the treatment units of the final part of the study period together with bicarbonate and ammonium values, which presented their highest values at the end of the experiment.
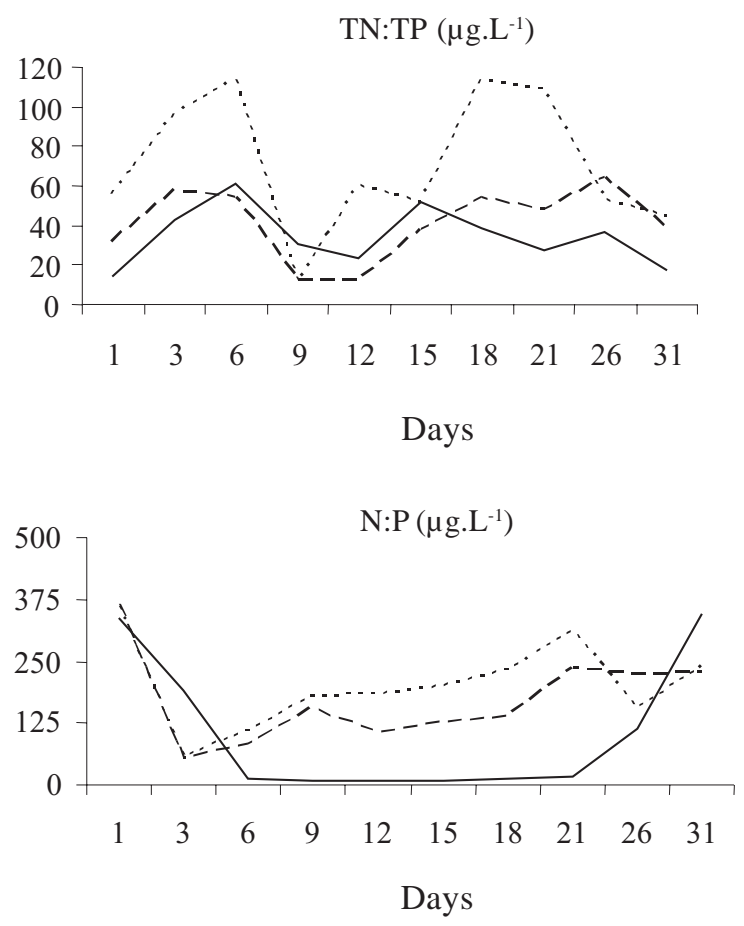

Figure 4. Temporal variation of mean values of $\mathrm{N}: \mathrm{P}$ (dissolved nutrients) and TN:TP ratio $(\mathrm{n}=2)$ in three treatments during the experiment period. - = Eutrophic, ---- = Mesotrophic, $\ldots$. = Oligotrophic.
Table 5. Abiotic variable correlations $(\mathrm{n}=30)$ with principal components.

\begin{tabular}{|c|c|c|}
\hline Variable & Axis 1 & Axis 2 \\
\hline $\mathrm{NH}_{4}^{+}$ & 0.006 & -0.655 \\
\hline $\mathrm{NO}_{2}^{-}$ & -0.427 & 0.350 \\
\hline $\mathrm{NO}_{3}^{-}$ & 0.679 & 0.395 \\
\hline $\mathrm{TN}$ & -0.888 & 0.092 \\
\hline $\mathrm{PO}_{4}^{3-}$ & -0.577 & 0.440 \\
\hline TDP & -0.933 & -0.223 \\
\hline TP & -0.942 & -0.004 \\
\hline $\mathrm{Si}$ & 0.027 & 0.759 \\
\hline Conductivity & -0.948 & -0.212 \\
\hline $\mathrm{pH}$ & -0.945 & 0.273 \\
\hline DO & -0.333 & 0.853 \\
\hline Free $\mathrm{CO}_{2}$ & 0.719 & -0.278 \\
\hline $\mathrm{HCO}_{3}^{-}$ & -0.670 & -0.665 \\
\hline $\mathrm{CO}_{3}^{-}$ & -0.790 & 0.478 \\
\hline Explained variation & $56.6 \%$ & $19.8 \%$ \\
\hline
\end{tabular}

Biological variables: chlorophyll $a$ and phaeophytin - Chlorophyll $a$ concentrations declined in all treatments during the study. Eutrophic treatment showed highest values of chlorophyll $a$ on day 12 (611.5 $\left.\mu \mathrm{g} . \mathrm{L}^{-1}\right)$, whereas the mesotrophic did so on day $3\left(69.4 \mu \mathrm{g} . \mathrm{L}^{-1}\right)$ and the oligotrophic on the $1^{\text {st }}$ day $\left(30.72 \mu \mathrm{g} . \mathrm{L}^{-1}\right)$ (table 6 , figure 6). Such a decline confirmed reduced photosynthetic activity that was also evidenced by the increase in free $\mathrm{CO}_{2}$ concentrations, low alkalinity values and $\mathrm{pH}$ reduction.

Phaeophytin values were higher than those of chlorophyll $a$ and also declined throughout the experiment. Phaeophytin concentration followed those of chlorophyll $a$, thus suggesting that the phytoplankton community started to senesce from the start of the experiment. Consequently, its falling phothosynthetic rates were evident due to the prominent decrease of the dissolved oxygen mean values, mainly in the diluted mesocosms. Maximum phaeophytin value in the eutrophic treatment was registered on the $12^{\text {th }}$ day (624.2 $\mu$ g. $\mathrm{L}^{-1}$ ), while in the mesotrophic one it was measured on the $9^{\text {th }}$ day $\left(74.3 \mu \mathrm{g} . \mathrm{L}^{-1}\right)$ and in the oligotrophic one on the $1^{\text {st }}$ day $\left(29.84 \mu \mathrm{g} . \mathrm{L}^{-1}\right)$ (table 6, figure 6).

Phytoplankton total density - Eutrophic treatment presented phytoplankton total density increase (42,766 ind. $\left.\mathrm{mL}^{-1}\right)$ up to the $9^{\text {th }}$ day, declining afterwards. The mesotrophic treatment presented the highest density value $\left(9,546\right.$ ind. $\left.\mathrm{mL}^{-1}\right)$ on the $6^{\text {th }}$ day, while the oligotrophic treatment did so on the $1^{\text {st }}$ day of study 


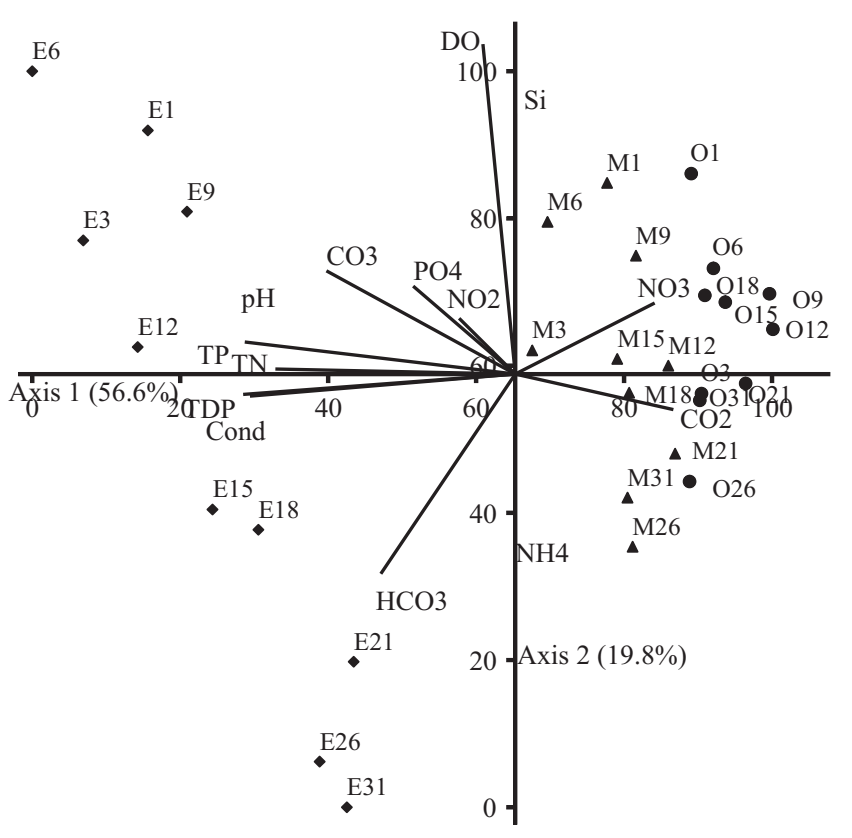

Figure 5. Biplot of PCA for mean values of abiotic variables of the three treatments during the experimental period. Abbreviations: Cond $=$ conductivity, $\mathrm{CO} 2=$ free carbonic gas, $\mathrm{DO}=$ dissolved oxygen, $\mathrm{TN}=$ total nitrogen, $\mathrm{pH}=\mathrm{pH}$, $\mathrm{TP}=$ total phosphorus, TDP = total dissolved phosphorus, $\mathrm{PO} 4=$ orthophosphate, $\mathrm{HCO} 3=$ bicarbonate, $\mathrm{CO} 3=$ carbonate, $\mathrm{NH} 4=$ ammonium, $\mathrm{NO} 2=$ nitrite, $\mathrm{NO} 3=$ nitrate, $\mathrm{Si}=$ silicate, $\mathrm{O} 2=$ dissolved oxygen, $\mathrm{E}=$ eutrophic treatment, $\mathrm{M}=$ mesotrophic treatment, $\mathrm{O}=$ oligotrophic treatment. Numbers following abbreviations indicate day of experiment. Treatments: $\bullet=$ Eutrophic, $\boldsymbol{\Delta}=$ Mesotrophic, $\bullet=$ Oligotrophic.

(3,047 ind. $\mathrm{mL}^{-1}$ ) (table 6, figure 7). Mean values of phytoplankton total density were significantly different among treatments $(\mathrm{F}=97.9 ; p=0.0001)$. Phytoplankton total density declined during the experiment period in all mesocosms, a tendency that was also registered for chlorophyll $a$ and phaeophytin concentrations after nutrient impoverishment. Thus, reduction of nutrient supply of eutrophic water led to a decrease of photosynthetic biomass both in oligo and mesotrophic mesocosms. A similar reduction of photosynthetic biomass was observed in eutrophic treatments.

Floristic composition of phytoplankton community-Total of 113 taxa was identified in all three systems together. In the eutrophic treatment eight algal taxonomic classes were identified, of which Cyanophyceae dominated throughout the study, representing $80.91 \%$ of phytoplankton total density. Cyanophyceae was immediately followed by Cryptophyceae $(9.49 \%)$ and Chlorophyceae (7.21\%) (table 7, figure 8).

Relative density of Cyanophyceae grew until the $9^{\text {th }}$ day, after which it declined considerably until the last day of the experiment. The space left by the gradual decrease in number of the blue greens was immediately occupied by Cryptophyceae and Chlorophyceae. Up to day 15 of the experiment, presence of Euglenophyceae and Chrysophyceae representatives was noted, their relative densities increasing up to the last day of the experiment. Dinophyceae occurred, although always in low densities, at the end of the study period when competition among the other algal groups declined in the mesocosms.

Eight algal classes were identified in the mesotrophic mesocosms (table 7, figure 8). As already happened in the eutrophic treatment, Cyanophyceae were dominant throughout the study period contributing with $75.09 \%$ of phytoplankton total density, being immediately followed by Chlorophyceae (11.27\%) and Euglenophyceae (7.25\%).

Blue greens in mesotrophic mesocosms presented a small increase in relative density during first days of study. However, a significant reduction of its biomass was registered. Cryptophyceae benefited from the space

Table 6. Minimum and maximum values and, between parenthesis, mean and standard deviation $(\mathrm{n}=9)$ for biological variables in three treatments during the experiment period.

\begin{tabular}{lccc}
\hline Treatments & $\begin{array}{c}\text { Chlorophyll } a \\
\left(\mu \mathrm{g} . \mathrm{L}^{-1}\right)\end{array}$ & $\begin{array}{c}\text { Phaeophytin } \\
\left(\mu \mathrm{g} . \mathrm{L}^{-1}\right)\end{array}$ & $\begin{array}{c}\text { Total density } \\
(\text { ind.ml }\end{array}$ \\
\hline Eutrophic & $90.6-611.5$ & $84.0-624.2$ & $23,706.0-42,766.0$ \\
& $(325.3 \pm 58.6)$ & $(309.2 \pm 62.7)$ & $(31,742.0 \pm 2,006.0)$ \\
Mesotrophic & $0.0-69.4$ & $2.5-74.3$ & $3,205.0-9,546.0$ \\
& $(26.3 \pm 8.8)$ & $(33.6 \pm 10.3)$ & $772.0 \pm 651.0)$ \\
Oligotrophic & $0.0-30.7$ & $0.92-29.8$ & $(1,853.0 \pm 226.0$ \\
& $(6.3 \pm 3.5)$ & $(7.5 \pm 3.4)$ & \\
\hline
\end{tabular}


left by the cyanophytes. Benefiting from the nutrient concentration dilution in the mesotrophic treatment, Euglenophyceae and Bacillariophyceae showed their highest relative density values during the beginning of the experiment. Chrysophyceae reached their highest density towards the middle of the experiment period, when no other algal group was at its maximum. Dinophyceae, Zygnemaphyceae and Chlorophyceae grew best by the end of the study period, when no other individual class density decreased and nutrient condition was very similar to that of the oligotrophic treatment.

Eutrophic
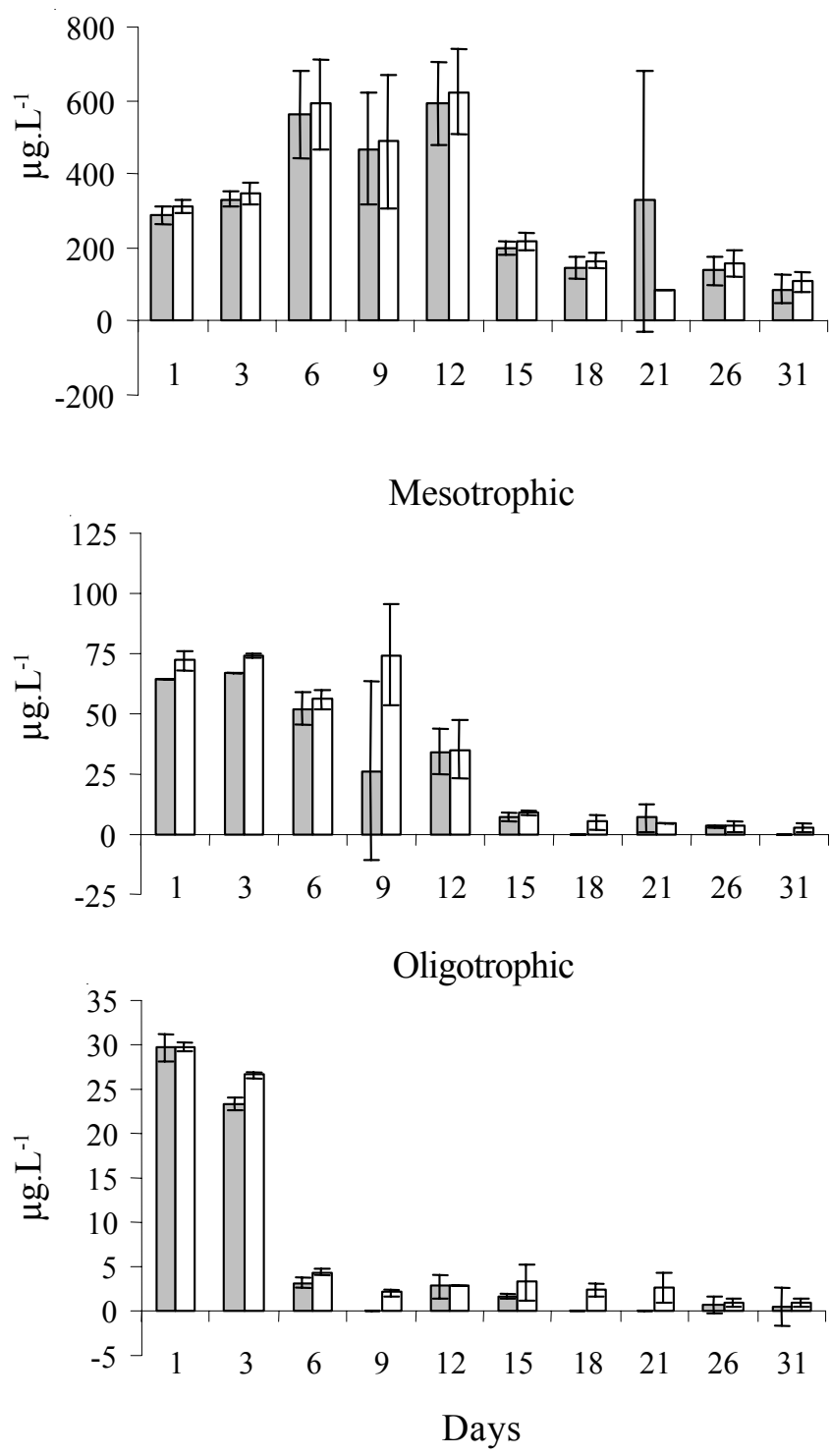

Figure 6. Temporal variation of mean concentration and standard deviation $(\mathrm{n}=2)$ of chlorophyll $a\left(\mu \mathrm{g} . \mathrm{L}^{-1}\right)$ and phaeophytin $\left(\mu \mathrm{g} . \mathrm{L}^{-1}\right)$ in three treatments during the experiment period. $\square=$ Chlorophyll $a, \square=$ Phaeophytin.

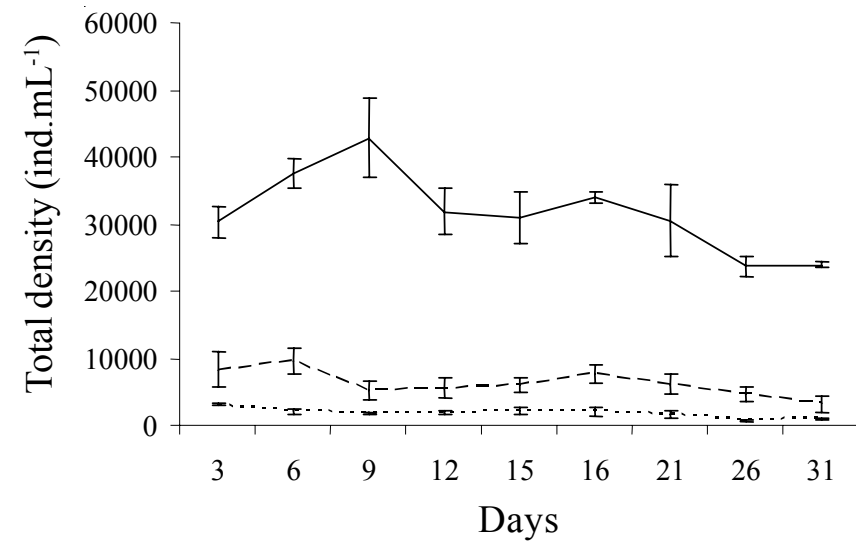

Figure 7. Temporal variation (mean concentration and standard deviation, $\mathrm{n}=2$ ) for total phytoplankton density in three treatments during the experiment period. - = Eutrophic, ---- $=$ Mesotrophic, $\cdots=$ Oligotrophic.

In the oligotrophic treatment, 7 algal classes occurred and Cyanophyceae was once more dominant during the entire study period, contributing with $80.75 \%$ of phytoplankton total density in the mesocosms. Cyanophytes were immediately followed by Chlorophyceae (9.45\%) and Euglenophyceae (5.63\%) (table 7 , figure 8 ). In this treatment, cyanophytes dominated during the beginning of the study period and declined afterwards, although an increase in their density on the $18^{\text {th }}$ day of the experiment was observed. Space left by the blue greens was immediately occupied by the Cryptophyceae and Euglenophyceae. Again, Crysophyceae grew best when no other algal group peaked. At the end of the experiment period, Dinophyceae, Zygnemaphyceae, and Chlorophyceae were favored by all other algal groups density decrease and when nutrient condition of the mesocosms became stable.

Table 7. Percentage (\%) of algal classes contribution in three treatments during experiment period.

\begin{tabular}{lccc}
\hline & \multicolumn{3}{c}{ Treatment } \\
\cline { 2 - 4 } Algal class & Oligotrophic & Mesotrophic & Eutrophic \\
\hline Bacillariophyceae & 0.06 & 0.11 & 0.00 \\
Chlorophyceae & 7.21 & 11.27 & 9.45 \\
Chrysophyceae & 0.11 & 5.83 & 2.44 \\
Cryptophyceae & 9.49 & 0.29 & 1.66 \\
Cyanophyceae & 80.91 & 75.09 & 80.75 \\
Dinophyceae & 0.10 & 0.03 & 0.02 \\
Euglenophyceae & 2.10 & 7.25 & 5.63 \\
Zygnemaphyceae & 0.03 & 0.13 & 0.06 \\
\hline
\end{tabular}




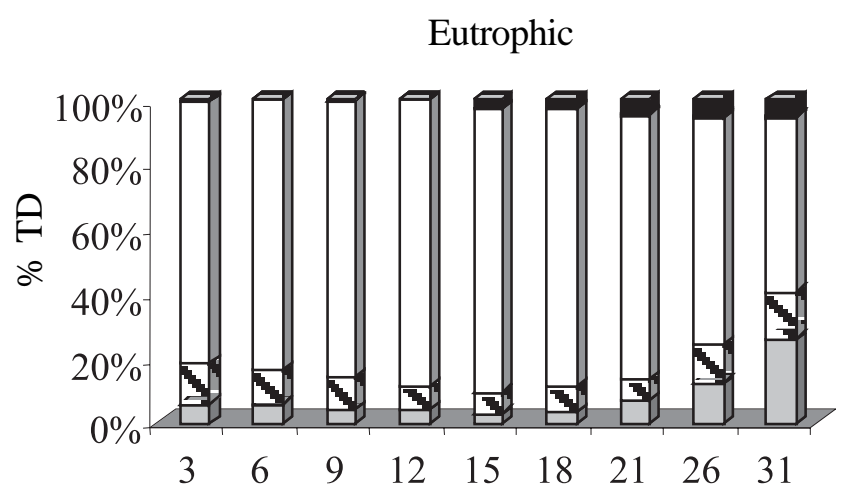

Mesotrophic

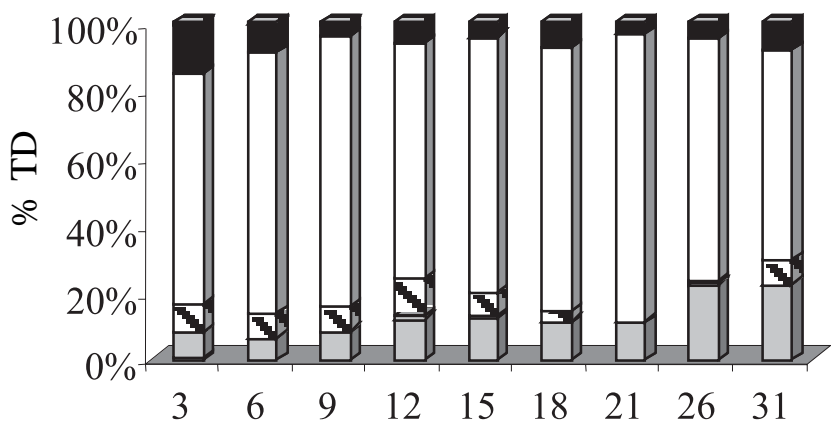

Oligotrophic

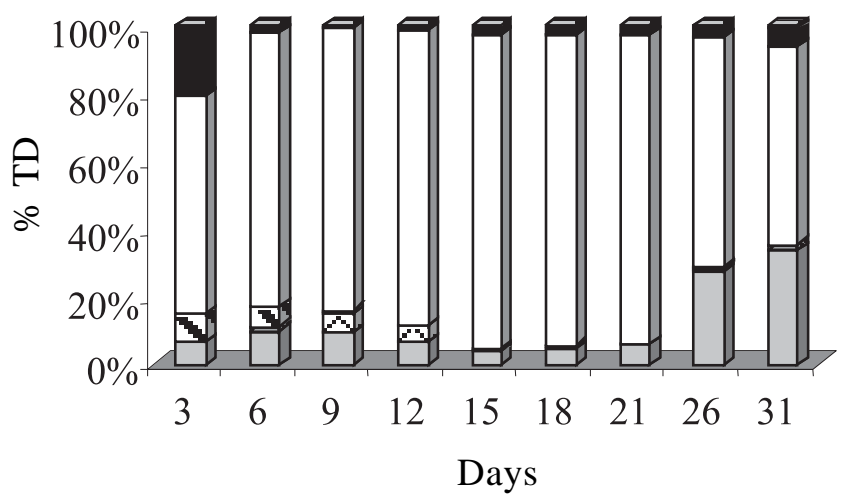

Figure 8. Temporal variation (mean algal class densities, $\mathrm{n}=2$ ) in three treatments during the experiment period. : $\mathbf{N}$ = Cryptophyceae, $\square$ = Cyanophyceae, $\mathbf{W}$ = Dinophyceae, - = Euglenophyceae, = 团 Zygnemaphyceae.

Integrated analysis of abiotic and biological variables Ordination of eutrophic, mesotrophic, and oligotrophic treatments sample units using Canonical Correspondence Analysis (CCA) explained $43.3 \%$ of the variability of biological data in the first 2 axes (table 8 , figure 9). Pearson's correlations between species and environment were high at both axes (respectively, $r=0.934$ and 0.835 ), indicating a strong relationship among abiotic and phytoplankton variables of the system. Monte Carlo test indicated that ordination between axes 1 and 2 ( $p \leq 0.05$ ) was significant and that such ordination was not at random.

Table 8. CCA synthesis for the three treatments' data.

\begin{tabular}{|c|c|c|c|}
\hline \multicolumn{2}{|l|}{ Result synthesis } & Axis 1 & Axis 2 \\
\hline \multicolumn{2}{|l|}{ Eigen values } & 0.289 & 0.134 \\
\hline \multicolumn{2}{|l|}{$\%$ of variance explained } & 29.6 & 13.7 \\
\hline \multicolumn{2}{|l|}{ Cumulative \% explained } & 29.6 & 43.3 \\
\hline \multicolumn{2}{|c|}{$\begin{array}{l}\text { Pearsons correlation } \\
\quad \text { (Species-Environment) }\end{array}$} & 0.934 & 0.835 \\
\hline \multirow[t]{3}{*}{ Monte Carlo Test $(p)$} & Eigen values & 0.010 & 0.010 \\
\hline & Correlations & 0.010 & 0.010 \\
\hline & \multicolumn{3}{|c|}{ Species-Environment } \\
\hline
\end{tabular}

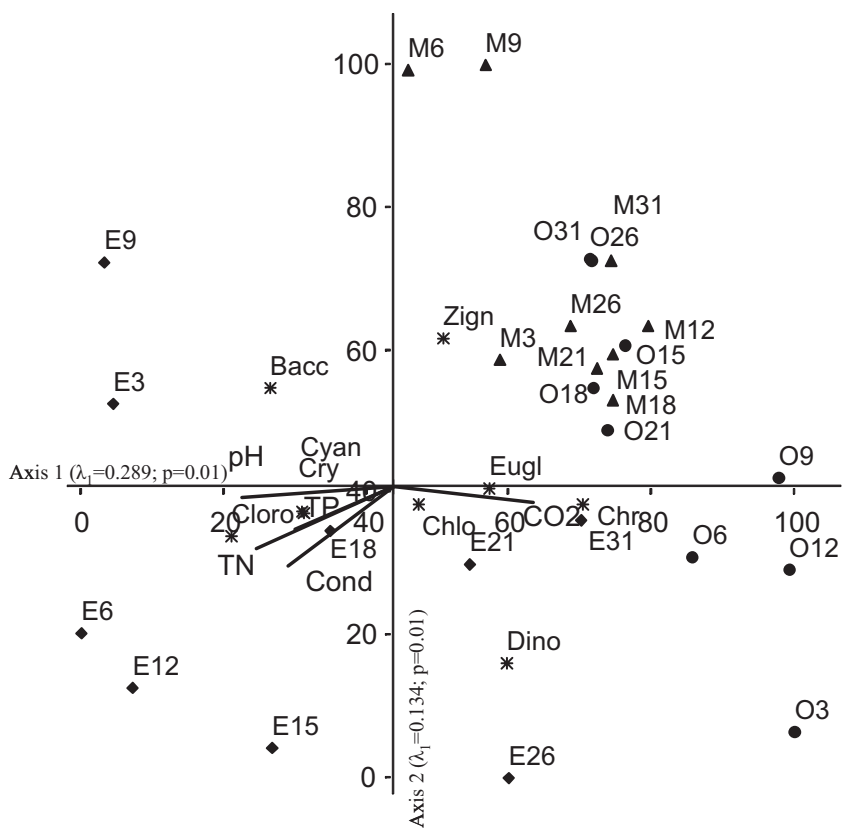

Figure 9. CCA Biplot for mean values of 10 abiotic and nine biological variables of the three treatments during study period. Abbreviations: $\mathrm{Bac}=$ Bacillariophyceae, $\mathrm{Chr}=$ Chrysophyceae, Chlo = Chlorophyceae, Cloro = chlorophyll $a$, Cry = Cryptophyceae, Cyan $=$ Cyanophyceae, Dino $=$ Dinophyceae, Eugl = Euglenophyceae, Zygn = Zygnemaphyceae, Cond = conductivity, $\mathrm{CO} 2=$ free $\mathrm{CO}_{2}, \mathrm{TN}$ $=$ total nitrogen, $\mathrm{pH}=\mathrm{pH}, \mathrm{TP}=$ total phosphorus, $\mathrm{E}=$ eutrophic treatment, $\mathrm{M}=$ mesotrophic treatment, $\mathrm{O}=$ oligotrophic treatment. Numbers following abbreviations indicate day of experiment. Treatments: $\bullet=$ Eutrophic, $\boldsymbol{\Delta}=$ Mesotrophic, $\bullet$ = Oligotrophic. 
Canonical coefficients showed (table 9) that $\mathrm{pH}$ was the most important variable for axis 1 ordination, a fact that was also indicated in the intra-set correlations. On one hand, at the positive side of axis 1 , all mesotrophic sampling units and most of the oligotrophic ones were associated to the higher free $\mathrm{CO}_{2}$ values, low $\mathrm{pH}$, $\mathrm{TN}$, TP values, and to electric conductivity. The negative side concentrated, on the other hand, the eutrophic sampling units of the study's first period, which were associated to the higher $\mathrm{pH}$ values. Chrysophyceae were associated to higher free $\mathrm{CO}_{2}$ values and to the diluted treatments, where these algae occurred in greater densities. Zygnemaphyceae were associated to meso and oligotrophic treatments, while the Bacillariophyceae concentrated near the eutrophic sample units from the beginning of the experiment. Dinophyceae were associated to the eutrophic treatment sampling units collected during the last days of the experiment. Near the highest nutrients values and closer to the eutrophic sampling units were the Cyanophyceae, Cryptophyceae, and chlorophyll $a$ values which presented the highest correlation with the $1^{\text {st }}$ axis (table 10).

Table 9. Canonical coefficients and intra-set correlation of environmental variables with axes 1 and 2 for 10 abiotic variables in the three treatments.

Cannonical coefficients Correlation coefficients (intra set)

\begin{tabular}{lcccc}
\hline Variables & Axis 1 & Axis 2 & Axis 1 & Axis 2 \\
$\mathrm{TN}$ & 0.041 & -2.724 & -0.885 & -0.383 \\
$\mathrm{TP}$ & -0.022 & -0.947 & -0.639 & -0.267 \\
Conductivity & 0.034 & 0.141 & -0.679 & -0.492 \\
$\mathrm{pH}$ & -0.899 & 2.614 & -0.983 & -0.074 \\
Free $\mathrm{CO}_{2}$ & 0.379 & -0.382 & 0.917 & -0.106 \\
\hline
\end{tabular}

Table 10. Biological variables correlation $(n=30)$ with axes 1 and 2.

\begin{tabular}{lcc}
\hline Variable & Axis 1 & Axis 2 \\
\hline Chlorophyll $a$ & -0.872 & -0.362 \\
Bacillariophyceae & -0.657 & 0.136 \\
Chlorophyceae & -0.340 & -0.301 \\
Chrysophyceae & 0.317 & -0.329 \\
Cryptophyceae & -0.806 & -0.343 \\
Dinophyceae & 0.000 & -0.396 \\
Euglenophyceae & -0.085 & -0.277 \\
Zygnemaphyceae & -0.201 & 0.325 \\
Cyanophyceae & -0.881 & -0.389 \\
\hline
\end{tabular}

Despite the low correlation with the $2^{\text {nd }}$ axis, $\mathrm{TN}$ $(r=-0.487)$ and conductivity $(r=-0.470)$ were the most important variables for the ordination of this axis. Mesotrophic sampling units and most of the oligotrophic ones were associated to the lower TN concentration and conductivity.

In the eutrophic treatment algal classes associated were Cyanophyceae, Cryptophyceae, and Bacillariophyceae. In the diluted ones, mainly Zygnemaphyceae was associated. Euglenophyceae, Chlorophyceae and Chrysophyceae occurred in all treatments, what justifies their intermediate ordination to the sampling units.

\section{Discussion}

Dominance of cyanophytes at the Garças Pond had already been registered by Ramírez (1996), Moura (1996), Sant'Anna et al. (1997), and Gentil (2000). Heo \& Kim (1997) demonstrated, after studying the Soyang Lake in South Korea, that excessive growth of blue green algae took place in nitrogen rich environments. However, for a long time, it was quite clear that excessive growth of blue greens would rarely occur in waters with high $\mathrm{N}$ : P ratio. Smith (1983) observed that blue greens are scarce when the TN : TP ratio is $29: 1$, suggesting that changes in this rate by nutrient monitoring could be an efficient method for controlling these algal growths in nature. However, due to their ability to fix atmospheric nitrogen, blue greens can maintain high growth rates under inorganic nitrogen deficiency. Consequently, they are competitors under nitrogen limited circumstances (Smith 1983).

During the present experiment, other algal classes were presumably established after nutrient impoverishment depending on their survival strategies. Changes were observed in the taxonomic composition of the phytoplankton community, with Chlorophyceae, Chrysophyceae and Cryptophyceae benefiting from blue green algae density decrease. Shapiro (1973) reported phytoplankton floristic changes related to nutrient changes due to the enrichment (addition of $\mathrm{N}, \mathrm{P}$, and $\mathrm{CO}_{2}$ ) and $\mathrm{pH}$ manipulation in polyethylene bags. $\mathrm{CO}_{2}$ increase or $\mathrm{pH}$ decrease stimulated changes in the phytoplankton community structure first dominated by blue green algae and afterwards by the Chlorophyceae, especially when $\mathrm{N}, \mathrm{P}$, and $\mathrm{CO}_{2}$ were simultaneously added to the bags (Shapiro, 1973). Enrichment with only $\mathrm{N}$ and $\mathrm{P}$ favored growth of blue green algae. Shapiro (1973) stated that under low $\mathrm{pH}$ circumstances, addition of $\mathrm{CO}_{2}$ reduced blue green algae density, without 
eliminating them from mesocosms. Blue greens just became less abundant. On the other hand, new conditions in the bags eliminated zooplankton. As a consequence of grazing interference reduction, Chlorophyceae could then develop better.

Sant'Anna et al. (1997) stated that after the decline of Microcystis aeruginosa (Kützing) Kützing population density, reestablishment of Chlorophyceae and Cryptophyceae could occur in this reservoir. Identical situation occurred in the present study. Excessive growth of blue green algae that can fix nitrogen depends not only on low $\mathrm{N}$ : P ratios, but also on sufficient P supply to the system (Stockner \& Shortreed 1988). According to Murphy \& Lean (1976), other algal groups may be completely suppressed during excessive growth of blue greens.

Chlorophyceae benefited from the decrease of blue greens density in the reservoir by occupying niches that were freed by the latter mainly because of their great cellular organization diversity, morphological structure, and reproductive processes. As a consequence of such properties, Chlorophyceae can exhibit a wide spectrum of responses and survival strategies to critical environmental variables, including nutrient availability. If one single environment and one same temporal niche are considered, nutrient supply can change the kind of dominant Chlorophyceae (Happey-Wood 1988). Many of the green algae observed by Krienitz et al. (1996) are R-strategists, with rapid growth rate, but the very same authors also referred to the occurrence of K-strategists, especially Volvocales that are much more resistant to grazing pressure.

Chrysophyceae was established in mesocosms when $\mathrm{pH}$ values decreased and no other algal group reached its maximum. Many Chrysophyceae require low light intensity and P concentration (Nixdorf et al. 1998). Other strategy of the chrysophytes is their ability to produce phosphatases, thus adapting to situations of low nutrient supply. Chrysophyceae are nutritional opportunists and many of them have autotrophic and phagotrophic heterotrophic mechanisms to obtain energy under environmental pressure (Sandgren 1988).

It is well known that phytoplankton have different survival strategies and that some species can take $\mathrm{P}$ more efficiently than others, leading to great advantage under stress situations. Thus, in eutrophic environment restoration processes, phytoplankton community composition will change with nutrient (mainly P) supply reduction and, consequently, will also alter some of its biological characteristics such as, for example, biovolume, population density, and chlorophyll $a$ concentration.

Several studies carried out in restored systems or in those undergoing recovery showed some floristic changes in the phytoplankton community, their biomass, and/or in the chlorophyll $a$ values after changes in nutrient concentration (Heyman \& Lundgren 1988, Dodds et al. 1993, Krienitz et al. 1996, Padisák \& Reynolds 1998). Blue green algae reduction was also registered in systems with nutritional depletion as showed by Cronberg (1999) and Barbieri \& Simona (2001). Annadotter et al. (1999) pointed out, after restoration of Finjasjön Lake (Sweden), a reduction in the total biomass and phytoplankton floristic composition. The initial Microcystis monoculture was replaced by a taxonomically diversified algal community composed of diatoms, cryptomonads, chrysophytes, and dinoflagellates. At the same time, TP concentration and biomass and chlorophyll $a$ values were considerably lower. Those observations were close to those registered in the present study.

Nutrient input is essential for phytoplankton floristic composition in natural communities. In the present study, nutrient impoverishment led to phytoplankton biomass reduction that could be demonstrated by phytoplankton total density, chlorophyll $a$, and phaeophytin values. After dilution procedures, chlorophyll $a$ concentration was reduced 12 times in the mesotrophic and 51 times in the oligotrophic treatments, whereas phytoplankton total density values decreased in these treatments, respectively, nine and 48 times. Reduction of Cyanophyceae and reestablishment of other algal groups such as Cryptophyceae, Chlorophyceae, Chrysophyceae, and Euglenophyceae, some of them with survival strategies adapted to nutritionally impoverished environment, allowed the conclusion that those techniques may be efficient during the system's restoration.

Eutrophication is the present cause of many problems. Much effort is being directed to them not only by approaching the environment recovery, but also by trying experimental procedures with the main purpose of creating or adapting techniques that will make recovery more accessible in terms of costs. It is finally proposed that isolation of allochthonous sources of nutrients should be the first step for restoration of the Garças Pond, however, keeping in mind that any recovery program adopted must aim at the reservoir's biocoenosis equilibrium. 
Acknowledgements - L.O. Crossetti is grateful to Fapesp, Fundação de Amparo à Pesquisa do Estado de São Paulo (Fellowship n. 00/08916-4) and C.E.M. Bicudo to CNPq, Conselho Nacional de Desenvolvimento Científico e Tecnológico (Grant n. 304643/90-4) for partial financial support.

\section{References}

ALTAFIN, J.G., MATTOS, S.P., CAVALCANTI, C.G.B. \& ESTUQUI, V.R. 1995. Paranoá Lake: limnology and recovery program. In Limnology in Brazil (J.G. Tundisi, C.E.M. Bicudo \& T. Matsumura-Tundisi, eds.). Academia Brasileira de Ciências/Sociedade Brasileira de Limnologia, Rio de Janeiro, p.325-349.

ANNADOTTER, R.H., CRONBERG, G., AAEGREN, R., LUNDSTEDT, B., NILSSON, R.A. \& STROBECK, S. 1999. Multiple techniques for lake restoration. Hydrobiologia 395-396:77-85.

BARBIERI, A. \& SIMONA, M. 2001. Trophic evolution of Lake Lugano related to external load reduction: changes in phosphoros and nitrogen as well as oxygen balance and biological parameters. Lakes \& Reservoirs: Research and Management 6:37-47.

BARBOSA, L.M.B., POTOMATI, A. \& PECCININI, A.A. 2002. PEFI: histórico e legislação. In Parque Estadual das Fontes do Ipiranga (PEFI): unidade de conservação que resiste à urbanização de São Paulo. (D.C. Bicudo, M.C. Forti \& C.E.M. Bicudo, eds.). Secretaria do Meio Ambiente do Estado de São Paulo, São Paulo, p.15-28.

BICUDO, C.E.M., CARMO, C.F., BICUDO, D.C., PIÃO, A.C.S., SANTOS, C.M. \& LOPES, M.R.M. 2002. Morfologia e morfometria de três reservatórios do PEFI. In Parque Estadual das Fontes do Ipiranga (PEFI): unidade de conservação que resiste à urbanização de São Paulo. (D.C. Bicudo, M.C. Forti \& C.E.M. Bicudo, eds.). Secretaria do Meio Ambiente do Estado de São Paulo, São Paulo, p.43-160.

BICUDO, D.C. 1990. Considerações sobre metodologias de contagens de algas do perifíton. Acta Limnologica Brasiliensia 3: 459-475.

BICUDO, D.C., FORTI, M.C., CARMO, C.F., BOUROTTE, C., BICUDO, C.E.M., MELFI, A.J. \& LUCAS, Y. 2002. A atmosfera, as águas superficiais e os reservatórios no PEFI: caracterização química. In Parque Estadual das Fontes do Ipiranga (PEFI): unidade de conservação que resiste à urbanização de São Paulo. (D.C. Bicudo, M.C. Forti \& C.E.M. Bicudo, eds.). Secretaria do Meio Ambiente do Estado de São Paulo, São Paulo, p.161-200.

BOZELLI, R.L., ESTEVES, F.A. \& ROLAND, F. 2000. Lago Batata: impacto e recuperação de um ecossistema amazônico. Universidade Federal do Rio de Janeiro/ Sociedade Brasileira de Limnologia, Rio de Janeiro.
CARMO, C.F., HENRY, R., BICUDO, D.C. \& BICUDO, C.E.M. 2002. A degradação nos reservatórios do PEFI. In Parque Estadual das Fontes do Ipiranga (PEFI): unidade de conservação que resiste à urbanização de São Paulo. (D.C. Bicudo, M.C. Forti \& C.E.M. Bicudo, eds.). Secretaria do Meio Ambiente do Estado de São Paulo, São Paulo, p.271-296.

CERRAO, G.C., MOSCHINI-CARLOS, V., SANTOS, M.J. \& RIGOLIN, O. 1991. Efeito do enriquecimento artificial sobre a biomassa do perifíton em tanques artificiais na Represa do Lobo (“Broa”). Revista Brasileira de Biologia 51:71-78.

CRONBERG, G. 1999. Qualitative and quantitative investigation of phytoplankton in Lake Ringsjön, Scania, Sweden. Hydrobiologia 404:27-40.

CRONBERG, G., ANNADOTTER, H. \& LAWTON, L.A. 1999. The ocurrence of toxic blue-green algae in Lake Ringsjön, southern Sweden, despite nutrient reduction and fish biomanipulation. Hydrobiologia 404:123-129.

DODDS, W.K. \& RANDEL, C. 1992. Field assessment of the effects of nutrient removal on phytoplankton productivity and biomass. Journal of Freshwater Ecology 7:283-292.

DODDS, W.K., STRAUSS, E.A. \& LEHMANN, R. 1993. Nutrient dilution and removal bioassays to estimate phytoplankton response to nutrient control. Archiv für Hydrobiologie 128(4):467-481.

FERNANDES, A.J., REIS, L.A.M. \& CARVALHO, A. 2002. Caracterização do meio físico. In Parque Estadual das Fontes do Ipiranga (PEFI): unidade de conservação que resiste à urbanização de São Paulo. (D.C. Bicudo, M.C. Forti \& C.E.M. Bicudo, eds.). Secretaria do Meio Ambiente do Estado de São Paulo, São Paulo, p.49-62.

FERRAGUT, C. 1999. Efeito do enriquecimento por N e P sobre a colonização e sucessão da comunidade de algas perifíticas: biomanipulação em reservatório oligotrófico, São Paulo. Dissertação de Mestrado, Universidade Estadual Paulista, São Paulo.

GENTIL, R.C. 2000. Variação sazonal do fitoplâncton em um lago subtropical eutrófico e aspectos sanitários, São Paulo. Dissertação de Mestrado, Universidade de São Paulo, São Paulo.

GOLTERMAN, H.L. \& CLYMO, R.S. 1971. Methods for chemical analysis of freshwaters. Blackwell Scientific Publications - International Biological Programme, Oxford and Edinburg.

GOLTERMAN, H.L., CLYMO, R.S. \& OHMSTAD, M.A.M. 1978. Methods for chemical analysis of freshwaters. Blackwell Scientific Publications, Oxford and Edinburg.

HAPPEY-WOOD, V.M. 1988. Ecology of freshwater planktonic green algae. In Growth and reproductive strategies of freshwater phytoplankton. (C.D. Sandreen, ed.). Cambridge University Press, Cambridge, p.175-226. 
HEO, W-M. \& KIM, B. 1997. The change in N/P ratio with eutrofication and cyanobacterial blooms in Lake Soyang, Korea. Internationale Vereinigung für Theorestische und Angewandte Limnologie 26:491-495.

HEYMAN, U. \& LUNDGREN, A. 1988. Phytoplankton biomass and production in relation to $\mathrm{P}$ (some conclusions from field studies). Hydrobiologia 170:211-227.

KRIENITZ, L., KASPRAZAK, P. \& KOSCHEL, R. 1996. Long term study on the influence of eutrofication, restoration and biomanipulation on the structure and development of phytoplankton communities in Feldberger Haussee (Baltic Lake District, Germany). Hydrobiologia 330:89-110.

LUND, J.W.G., KIPLING, C. \& LECREN, E.D. 1958. The invert microscope method of estimating algal numbers and the statistical basis of estimations by counting. Hydrobiologia 11:143-170.

MACKERET, F.J.H., HERON, J. \& TALLING, J.F. 1978. Water analysis: some revised methods for limnologists. Titus Wilson \& Son Ltda - Freshwater Biological Association Scientific Publication, Kendall.

McCUNE, B. \& MEFFORD, M.J. 1997. PC-ORD. Multivariate analysis of ecological data, version 3.0. MjM Software Design, Oregon.

MOURA, A.T.N. 1996. Estrutura e dinâmica da comunidade fitoplanctônica numa lagoa eutrófica, São Paulo, SP, Brasil, a curtos intervalos de tempo: comparação entre épocas de chuva e seca. Dissertação de Mestrado, Universidade Estadual Paulista, São Paulo.

MURPHY,T.P. \& LEAN, D.R.S. 1976. Blue-green algae: their excretion of Iron Selective chelators enables them to dominate other algae. Science 192:900-902.

NIXDORF, F.B., MISCHKE, U. \& LEbMANN, D. 1998. Chrysophytes and chlamydomonads: pioneer colonists extremely acidic minig lakes $(\mathrm{pH}<3)$ in Lusatia (Germany). Hydrobiologia 369-370:315-327.

PADISÁK, J. \& REYNOLDS, C.S. 1998. Selection of phytoplankton associations in Lake Balaton, Hungary, in response to eutrophication and restoration measures, with special reference to the cyanoprokariotes. Hydrobiologia 384:41-53.

PEARL, H.W. \& BOWLES, N.D. 1987. Dilution bioassays: their application to assessments of nutrient limitation in hypereutrophic waters. Hydrobiologia 146:265-273.

PERROW, M.R., MOSS, B. \& STRANSFIELD, J. 1994. Trophic interactions in a shallow lake following a reduction in nutrient loading: a long-term study. Hydrobiologia 275-276:43-52.

RAMÍREZ R., J.J. 1996. Variação espacial, vertical e nictimeral da estrutura da comunidade fitoplanctônica e variáveis ambientais em quatro dias de amostragem de diferentes épocas do ano no Lago das Garças, São Paulo. São Paulo. Tese de doutorado, Universidade de São Paulo, São Paulo.

RIP, W.J., EVERARDS, K. \& HOUWERS, A. 1992. Restoration of Bosthol (The Netherlands) by reduction of external nutrient load: the effects on physico-chemical conditions, plankton and sessile diatoms. Hydrobiological Bulletin 25:275-286.
SANDGREN, C.D. 1988. The ecology of chrysophyte flagellates: their growth and perennation strategies as freshwater phytoplankton. In Growth and reproductive strategies of freshwater phytoplankton. (C.D. Sandgren, ed.). Cambridge University Press. Cambridge. p.9-104.

SANT’ANNA, C.L., SORMUS, L., TUCCI, A. \& AZEVEDO, M.T.P. 1997. Variação sazonal do fitoplâncton no Lago das Graças, São Paulo. Hoehnea 24:67-89.

SARTORY, D.P. \& GROBBERLAAR, J.E. 1984. Extraction of chlorophyll a from freshwater phytoplankton for spectrophotometric analysis. Hydrobiologia 114:177-187.

SAS Institute Inc. 1996. SAS/STAT User's guide version. SAS Institute Inc., vol.1 and 2.

SHAPIRO, J. 1973. Blue-green algae: why they become dominant. Science 179:382-984.

SHEPHERD, G.J. 1996. Fitopac 1: manual do usuário. Departamento de Botânica, Universidade Estadual de Campinas, Campinas.

SMITH, V.H. 1983. Low nitrogen to phosphorus ratio favor dominance by blue-green algae in lake phytoplankton. Science 221:669-670.

SOLORZANO, L. 1969. Determination of ammonia in natural waters by the phenolhypochlorite method. Limnology \& Oceanography 14:799-801.

STOCKNER, J.G. \& SHORTREED, K.S. 1988. Response of Anabaena and Synechococcus to manipulation of N : P ratios in a lake fertilization experiment. Limnology \& Oceanography 33:796-822.

STRICKLAND, J.D.H. \& PARSONS, T.R. 1960. A manual of sea water analysis. Fisheries Research Board of Canada Bulletin 125:1-185.

SUZUKI, M.S. 1991. Mudanças na estrutura e sucessão das comunidades fitoplanctônicas e perifíticas da Lagoa do Infernão (SP), causada pelo processo de enriquecimento artificial (São Carlos). Dissertação de mestrado Universidade Federal de São Carlos, São Paulo.

TOLEDO, A.P., TALARICO, M., CHINEZ, J.S. \& AGUDO, E.G. 1983. A aplicação de modelos simplificados para a avaliação de processo de eutrofização em lagos e reservatórios tropicais. In XII Congresso Brasileiro de Engenharia Sanitária e Ambiental. Cetesb, Camboriú, p.1-34.

UTERMÖHL, H. 1958 Zur Vervolkomnung der quantitative Phytoplankton: Methodik Mitteilung Internationale Vereinigung Theoretische und Angewandte Limnologie 9:1-38.

VALDERRAMA, J.C. 1981. The simultaneous analysis of total nitrogen and total phosphorous in natural waters. Marine Chemistry 10:109-122.

WETZEL, R.G. 2001. Limnology: lakes and rivers ecosystems. Academic Press, San Diego.

WETZEL, R.G. \& LIKENS, G.E. 2000. Limnological analysis. Springer Verlag, New York. 